\title{
Bumping the Status Quo: Actual Relief for Actual Victims Under Title VII
}

\author{
Dale Carpenter $\dagger$
}

Congress enacted Title VII of the Civil Rights Act of 1964 (the Act $)^{1}$ in an effort to eradicate specified categories of discrimination in private employment. Following the increased political enfranchisement of nondominant groups, the Act proclaimed an official end to the era of second-class status for women and minorities in the workforce. ${ }^{2}$ It promised a new era of economic and personal opportunity to sectors of the population previously excluded. Title VII reflected the growing notion that formal political freedom meant little without real access to economic opportunity. ${ }^{3}$

A critical aspect of the Title VII scheme was to pressure employers by creating remedies for the victims of employment discrimination. Whole classes of plaintiffs, as well as individuals, could now seek redress in the courts, and the Act directed courts to fashion equitable relief for victims of proven discrimination. ${ }^{4}$ Such relief was to remedy the harm done to the individual plain-

$\dagger$ B.A. 1989, Yale University; J.D. Candidate 1992, The University of Chicago.

1 Pub L No 88-352 § 701 et seq, 78 Stat 253 (1964), codified as amended by the Equal Employment Opportunity Act of 1972, Pub L No 92-261, 86 Stat 103 (1972), at 42 USC $\S 2000 \mathrm{e}(1988)$.

2 Section 703(a) provides:

(a) It shall be an unlawful employment practice for an employer-

(1) to fail or refuse to hire or to discharge any individual, or otherwise to discriminate against any individual with respect to his compensation, terms, conditions, or privileges of employment, because of such individual's race, color, religion, sex, or national origin; or

(2) to limit, segregate, or classify his employees or applicants for employment in any way which would deprive or tend to deprive any individual of employment opportunities or otherwise adversely affect his status as an employee, because of such individual's race, color, religion, sex, or national origin.

42 USC § $2000 \mathrm{e}-2$ (a).

3 Said one member of the House Judiciary Committee: "The right to vote [] does not have much meaning on an empty stomach." Civil Rights Act of 1963, HR Rep No 914, Part 2, 88th Cong, 1st Sess 26 (1963) (additional views of Rep. McCulloch), reprinted in EEOC, Legislative History of Titles VII and XI of Civil Rights Act of 19642147 (GPO, 1968) ("Legislative History-1964"). Coming at the apex of the civil rights movement, Title VII culminated a drive that began by prohibiting discrimination in government employment and government contract employment. See id at 1-5.

- Section 706(g), 42 USC § $2000 \mathrm{e}-5(\mathrm{~g})$ (quoted in text at note 65). 
tiff, and also to deter future acts of discrimination by the defendant and other employers. ${ }^{5}$ Thus, the remedial side of Title VII kept one eye on the particular needs of the victim and the other on the phenomenon of discrimination itself.

This Comment addresses one possible remedy: "bumping." Discrimination charges often arise after an allegedly unlawful discharge, refusal to hire, or refusal to promote the plaintiff. After a victim proves liability, a court must determine how to compensate for the prohibited discrimination. Courts frequently order the employer to place the victim in the position she would have occupied but for the discrimination. When the employer has already filled the position, reinstatement ${ }^{6}$ means that the employer must "bump" the incumbent employee to make room for the discriminatee. ${ }^{7}$ Courts currently award bumping only under compelling and narrow circumstances. ${ }^{8}$

Many courts do not find the mere fact of discrimination sufficiently compelling to warrant immediate reinstatement. These courts perceive bumping as redressing the employer's wrong at the expense of an innocent third party, the incumbent. Instead, they require the victim to wait for the next available opening. This approach, known" as the "rightful place" doctrine, can result in long

- Albemarle Paper Co. $v$ Moody, 422 US 405, 417-18 (1975).

- This Comment uses- the term "reinstatement" as shorthand for the entire range of court-ordered employment remedies. Technically, "reinstatement" refers to an order placing the person in a position the person actually occupied before the act of discrimination. Thus, it typically relates to unlawful discharges. "Instatement" refers to an order placing the person in a position she would have occupied absent the discrimination. It encompasses hirings and promotions. The remedial provision of Title VII, $\$ 706(\mathrm{~g}), 42$ USC $\S 2000 \mathrm{e}-5(\mathrm{~g})$, allows for court-ordered "reinstatement," "hiring of employees," and "promotions." See text at note 65 .

7 The victim may not actually desire the unlawfully denied job. The victim may have found alternative employment, or residual animosity between the victim and the employer may discourage the victim from seeking reinstatement. A presumptive right to reinstatement, however, will have important antidiscrimination consequences. First, at least some Title VII victims will want reinstatement. Second, a presumptive reinstatement rule may have important preference-shaping consequences for victims. That is, the current reluctance of victims to request reinstatement may be less a function of factors such as those listed above than of the current legal rule restricting reinstatement. Third, even if the victim does not desire reinstatement, the entitlement to reinstatement will enhance the victim's bargaining position during settlement discussions. See Section II for the argument that reinstatement serves the text, history, and purposes of Title VII.

${ }^{8}$ See Lee v Macon County Bd. of Educ., 453 F2d 1104, 1112 (5th Cir 1971) (violation of court order); Brewer v Muscle Shoals Bd. of Educ., 790 F2d 1515, 1522-24 (11th Cir 1986) (violation of settlement agreement); Walters $v$ City of Atlanta, 803 F2d 1135, 1148-50 (11th Cir 1986) (defendant manifested recalcitrance and bad faith by repeated acts of discrimination). The DC Circuit may have begun a limited trend toward bumping in Lander $v$ Lujan, 888 F2d 153 (DC Cir 1989); see text at notes 50-63. 
delays for the discriminatee, especially when the illegally denied position is unique.

This Comment argues that bumping should be the rule, not the exception, for Title VII relief. Court-ordered bumping squares with the text, history, and prophylactic purposes of Title VII far better than alternate remedies do. Courts should minimize the inconvenience and unfairness to bumped incumbents by tailoring the bumping order, not by entrenching them in their jobs.

Section I examines the development of the rightful place doctrine. Section II argues for the appropriateness of bumping in light of Title VII's text, history, and purposes. Finally, Section III suggests an approach that gives greater scope to bumping as a remedy, and considers how courts can alleviate the hardship to the displaced incumbent.

\section{The Current Dominance of Rightful Place Relief Over BUMPING}

Title VII provides for the reinstatement of discriminatees. ${ }^{9}$ When the employer has already filled the position with another employee, the court may either order immediate reinstatement (displacing the incumbent), or delay reinstatement until the position becomes vacant and order compensatory pay in the interim (the rightful place remedy). This Section examines the development of the latter option as the preferred remedy.

\section{A. The Rightful Place Doctrine}

Courts developed the rightful place doctrine as an appropriate strategy in the limited context of pre-Act seniority systems, but have indefensibly expanded it beyond this original domain. Meanwhile, bumping typically has been reserved for situations involving employer bad faith or disregard of a court order, although one circuit court has slightly broadened its application.

1. Seniority system discrimination cases.

Supporters of Title VII made it clear that the Act's effect was to be purely prospective, not retrospective. ${ }^{10}$ That is, discrimina-

- Section 706(g), 42 USC $\S 2000 \mathrm{e}-5(\mathrm{~g})$ (quoted in text at note 65).

10 110 Cong Rec 7213 (April 8, 1964) (memorandum of Senators Clark and Case), reprinted in Legislative History-1964 at 3043 (cited in note 3) ("Clark-Case memorandum"). See Franks v Bowman Transportation Co., Inc., 424 US 747, 759 (1976) (quoting with approval from legislative history that Title VII is "prospective and not retrospective"); see also 
tory acts or practices occurring before the effective date of the Act could not form the basis of a Title VII violation. Yet some pre-Act practices tended to perpetuate the effects of discrimination "after the effective date. Insulating those practices from Title VII scrutiny would create an enormous barrier to progress for nondominant groups in employment. One such practice was the departmental seniority system. ${ }^{11}$

Prior to the Act's passage, some companies divided workers into groups or departments and assigned each department a particular task within the larger work force. Workers bid for job openings on the basis of their "departmental" seniority. ${ }^{12}$ Applying for an opening in another department meant starting at the bottom of that department's seniority roster, because seniority in one department did not count in another. Further, employers often strictly segregated departments, with blacks and other minorities relegated to the departments with less desirable, lower-paying jobs.

Title VII forbids racial exclusion by department. ${ }^{13}$ Blacks and other previously excluded groups could now apply for openings in any department, and employers had to evaluate their applications under nondiscriminatory criteria. Still, the old departmental seniority rosters put minorities at an acute disadvantage. They had to begin at the bottom of the formerly all-white department, even though their plant seniority with the employer might be comparable to, or exceed, those ranked significantly higher under departmental seniority. Courts thus faced the dilemma of what to do with seniority systems that, although facially nondiscriminatory, locked in pre-Act discrimination. Congress's clear intent not to punish pre-Act practices compounded the problem. Further, $\S 703(\mathrm{~h})$

Local 189, United Papermakers v United States, 416 F2d 980, 987 (5th Cir 1969) ("No one can quarrel with the broad proposition that Title VII operates only prospectively.").

${ }_{11}$ The seniority system cases do not involve departmental discrimination alone. Other seniority system issues-for example, lines of progression and layoffs-also plagued early Title VII litigation. See, for example, Watkins v United Steelworkers, Local 2369, 516 F2d 41 (5th $\mathrm{Cir}$ 1975). The rightful place doctrine developed as a general response to seniority systems. The following discussion uses the particular problem presented by departmental seniority systems to illustrate the general problem.

12 "Seniority" is susceptible to different measurements. "Employment," "mill," or "plant" seniority refers to total length of employment with the employer; "departmental" seniority refers to length of service in a department; "progression line" seniority refers to length of service in a line of progression; "job" seniority refers to length of service in a given job. George Cooper and Richard B. Sobol, Seniority and Testing Under Fair Employment Laws: A General Approach to Objective Criteria of Hiring and Promotion, $82 \mathrm{Harv} \mathrm{L}$ Rev 1598, 1602 (1969).

${ }^{13}$ Section 703(a), 42 USC $\S 2000 \mathrm{e}-2$ (a) (quoted in note 2). 
places "bona fide seniority systems" outside the Act's ambit. ${ }^{14}$ Courts solved this dilemma by crafting the rightful place doctrine.

The Fifth Circuit was the first appellate court explicitly to approve rightful place relief. In Local 189, United Papermakers $v$ United States, ${ }^{15}$ the employer organized employees into lines of progression whereby experience in each line served as training for the next. The employer reserved some lines of progression for whites and some for blacks. The least desirable white jobs generally paid more and delegated more responsibility than the best black jobs. ${ }^{16}$ Even after desegregation of the plant, blacks were at a tremendous disadvantage in applying for formerly white jobs because they had no seniority in white lines of progression. This, the court held, violated Title VII. ${ }^{12}$

The court first dutifully recited the widely accepted proposition that "Title VII operates only prospectively."18 It then considered three possible remedies in departmental seniority cases. ${ }^{19}$ The first, the "freedom now" theory, was the historical antecedent to bumping. Under this theory, the court would purge all the effects of past discrimination by placing blacks in the jobs they would have occupied but for the discrimination. Blacks with greater plant seniority would displace white incumbents. Allowing junior white employees to keep their jobs, in this view, itself constituted an act of discrimination. A second approach, the "status quo" theory, required only that employers stop present discrimination. Blacks hired before Title VII would have to compete on the basis of desegregated departmental seniority. Thus, departments would re-

14 Congress included $\S 703(\mathrm{~h})$ as a political compromise to ensure passage of the Act by reassuring labor leaders and others that the Act would not affect seniority systems. See American Tobacco Co. v Patterson, 456 US 63, 72 (1982).

15416 F2d 980 (5th Cir 1969). A year earlier, the district court in Quarles $v$ Philip Morris, Inc., 279 F Supp 505 (E D Va 1968), became the first federal court to adopt the theory. Declaring that "Congress did not intend to freeze an entire generation of Negro employees into discriminatory patterns," id at 516, the Quarles court ordered the employer to base bidding on plant seniority, not departmental seniority. Id at 521. The court dismissed the argument that such an arrangement would disrupt the departmental seniority expectations of white employees, declaring those expectations to be "not vested, indefeasible rights." Id at 520. Although the court did not adopt the rightful place doctrine by name, its remedy self-consciously drew upon a student note outlining the contours of that theory. Id at 510, citing Note, Title VII, Seniority Discrimination, and the Incumbent Negro, 80 Harv L Rev 1260 (1967).

$16416 \mathrm{~F} 2 \mathrm{~d}$ at 983 .

17 Id at $986,997$.

18 Id at 987.

19 Id at 988. The court's discussion relied heavily on Note, 80 Harv L Rev at 1268-69 (cited in note 15). 
main segregated until the work force turned over enough so that the new, nondiscriminatory seniority system had a real effect.

The Fifth Circuit adopted a third theory, the rightful place doctrine, as a compromise between the extremes of "freedom now" and "status quo":

The Act should be construed to prohibit the future awarding of vacant jobs on the basis of a seniority system that "locks in" prior racial classification. White incumbent workers should not be bumped out of their present positions by $\mathrm{Ne}$ groes with greater plant seniority; plant seniority should be asserted only with respect to new job openings. ${ }^{20}$

The court saw the rightful place doctrine as undoing the continuing effects of past discrimination (thereby serving the Act's purposes) without undoing past discrimination itself (by not removing junior white incumbents hired before the Act in favor of blacks with more plant seniority). In this way the court could fulfill the Act's antidiscrimination directive without applying Title VII retrospectively. The result was a seniority system remedy plausibly consistent with Title VII's language, history, and purposes.

In the seven years after Local 189, other circuits eagerly adopted the rightful place doctrine. ${ }^{21}$ Importantly, each of these courts applied the doctrine in situations that shared two key characteristics: plaintiffs claimed relief from seniority systems, the discriminatory characteristics of which pre-dated the Act. ${ }^{22}$ As will be seen, both of these characteristics clearly distinguish the early rightful-place cases from ones in which a victim proves post-Act, non-seniority system discrimination. ${ }^{23}$

$20416 \mathrm{~F} 2 \mathrm{~d}$ at 988 (emphasis in original).

21 See EEOC v Detroit Edison Co., 515 F2d 301, 316 (6th Cir 1975); Gamble v Birmingham Southern R.R. Co., 514 F2d 678, 683 (5th Cir 1975); United States v N.L. Industries, 479 F2d 354, 374-75 (8th Cir 1973); United States $v$ Chesapeake and Ohio Ry. Co., 471 F2d 582, 587-89 (4th Cir 1972); United States v Bethlehem Steel Corp., 446 F2d 652,661 (2d Cir 1971).

22 The seniority system at issue in Bethlehem Steel continued to discriminate two years after the effective date of Title VII. 446 F2d at 658. Still, the court emphasized the importance of its decision not to "freeze" in pre-Act discriminatory patterns. Id at 661-62 (citing Quarles, 279 F Supp at 516).

${ }^{23}$ In International Brotherhood of Teamsters $v$ United States, 431 US 324 (1977), the Supreme Court overruled the line of cases beginning with Quarles and Local 189. The Court ruled that $\$ 703(\mathrm{~h})$ protects seniority systems even if they tend to perpetuate the effects of pre-Act discrimination, as long as they were not designed to discriminate. Teamsters does not alter the analysis here, however, that courts developed the rightful place doctrine as a response to a limited problem. 
The Fourth Circuit expanded the application of the rightful place doctrine to include post-Act seniority system discrimination in Patterson $v$ American Tobacco $\mathrm{Co}^{24}$ The court explicitly considered-but refused to permit-the bumping of junior employees hired after the effective date of Title VII. ${ }^{25}$ The court first relied on an interpretive memorandum by Senators Clark and Case, cosponsors of Title VII, to support its view that Congress did not intend to authorize courts to bump incumbents. ${ }^{26}$ Second, the court described bumping as an "unsettling process" that would require judges periodically to rearrange the lives and businesses of incumbents and employers. ${ }^{27}$ Finally, the court contended that rightful place relief was indeed complete relief for victims, because they could receive compensatory pay until the employer actually promoted them. ${ }^{28}$ Thus, after Patterson, victims of post-Act discrimination were limited to the same relief as victims of pre-Act discrimination, despite the absence of the retrospectivity concern. ${ }^{29}$

From Local 189 to Patterson, then, courts applied the rightful place doctrine to seniority system cases. If the courts had continued to apply the doctrine merely to seniority system litigation, its importance in the debate over Title VII remedies would have diminished over time, because it would have applied only to individuals who accumulated seniority rights and job positions prior to $1964 .^{30}$ The inevitable decline of Title VII claims based on discrimination in seniority systems would have caused the doctrine to die a quiet death, without the need to consider whether the doctrine was consistent with Title VII as an initial matter. But since the late 1970s, courts have breathed new life into the doctrine by applying it well beyond its original domain.

24535 F2d 257 (4th Cir 1976).

28 Patterson was the first decision in which a court extensively considered bumping as a possible alternative to the rightful place doctrine.

26 The court's interpretation of this memorandum is questionable. See Section II.B.2. for discussion of the relevant legislative history cited in Patterson.

$27535 \mathrm{~F} 2 \mathrm{~d}$ at 268.

28 Id at 269.

20 In American Tobacco Co. $v$ Patterson, the Supreme Court effectively abolished the distinction between pre- and post-Act seniority systems. 456 US at 68 . The Court's decision, however, does not affect the analysis here. The rightful place doctrine developed as a response to the perceived need for an approach that balanced the Act's remedial purposes and its nonretrospective character. The Court did not address the propriety of the rightful place doctrine in American Tobacco.

so See Leroy D. Clark, The Future Civil Rights Agenda: Speculation on Litigation, Legislation, and Organization, 38 Cath U L Rev 795, 810 (1989). 
2. Application beyond seniority system cases.

After Patterson, the rightful place doctrine took hold as the generally accepted mechanism for Title VII relief. Courts applied the doctrine reflexively, not considering whether the original rationale for its use fit changing circumstances.

Harper $v$ General Grocers Co. ${ }^{31}$ was an early such extension. Superficially, Harper involved a dispute over seniority rights. The employer had advanced employees from temporary, "casual" status to regular, permanent status on the basis of seniority. Just before Harper was due to advance from the former category to the latter, the employer discharged him. Shortly thereafter, the employer advanced to permanent employment the employee who had been behind Harper on the casual list. ${ }^{32}$ Thus, the dispute over seniority rights really involved the wrongful denial of a single position to a single individual, ${ }^{33}$ rather than the systematic denial of advancement to a class of plaintiffs as in the previous seniority system cases.

The Eighth Circuit rejected Harper's request for immediate reinstatement because another employee already held the position he sought. The court characterized the choice as one between the "legitimate expectations of nonvictim employees" and the restoration of the victim to his "rightful place." 34 While the court noted that reinstatement would have afforded Harper "the most complete relief," it found the district court's refusal to so order not to be an abuse of discretion. ${ }^{35}$ The Harper court did not mention the district court's novel application of the rightful place doctrine to the one-on-one discrimination context. ${ }^{36}$

In Spagnuolo $v$ Whirlpool Corp. ${ }^{37}$ the Fourth Circuit pressed the rightful place doctrine beyond all previous bounds. The court determined that rightful place relief was compelled by "the con-

${ }^{31} 590$ F2d 713 (8th Cir 1979).

${ }^{32}$ Id at 715-16.

ss This is known as "one-on-one" discrimination.

${ }^{34} 590$ F2d at 716. See also Vaughn $v$ Westinghouse Elec. Corp., 471 F Supp 281, 291 (E D Ark 1979) (rightful place relief awarded out of concern that bumping displaces "innocent employees").

${ }^{35} 590$ F2d at 716-17. This Comment argues that reviewing courts should find such refusal to be an abuse of discretion. See note 101.

${ }^{38}$ The court cited as support two rightful place cases involving seniority system litigation. Id at 717 (citing Gamble, 514 F2d 683, and Reed v Arlington Hotel Co., 476 F2d 721, 726 (8th Cir 1973)).

${ }^{37} 717$ F2d 114 (4th Cir 1983). Spagnuolo was brought under the Age Discrimination in Employment Act (ADEA), 29 USC $\S 621$ et seq (1988), but the court applied the principles of Title VII. Id at 119-20. 
gressional process by which Title VII was enacted." 38 The Spagnuolo court took Patterson's reading of legislative history as a matter of faith-neglecting even to cite the critical interpretive memo by Senators Clark and Case-and thereby extended the already overbroad interpretation.

Spagnuolo completed the transformation of the rightful place theory from a limited doctrine applicable only in a narrow category of cases implicating pre-Act seniority system discrimination to "the generally appropriate mechanism for injunctive relief under Title VII."39 The rightful place doctrine now stood squarely between the victims of discrimination and their rightful places.

\section{B. Bumping in the Federal Courts}

Despite the reign of the rightful place doctrine in Title VII cases, courts on occasion have considered displacing incumbents in favor of proven victims of discrimination. The Supreme Court has discussed in dicta the relative merits of rightful place and bumping relief in Title VII cases. In Firefighters Local Union $v$ Stotts, ${ }^{40}$ a seniority system case, the Court noted that a victim of discrimination

is not automatically entitled to have a nonminority employee laid off to make room for him. He may have to wait until a vacancy occurs, and if there are nonminority employees on layoff, the court must balance the equities in determining who is entitled to the job.41

That a victim is "not automatically entitled" to incumbent displacement indicates that under some circumstances the victim may be entitled to such relief. The Court also noted, however, that the lower courts had "uniformly" denied bumping relief for actual victims. ${ }^{42}$ Bumping would be inappropriate "absent either a finding that the seniority system was adopted with discriminatory intent

38 Id at 121.

39 Id at 120. The facts of Spagnuolo demonstrate the extent of the hesitation to award bumping. It had been 30 months since the rightful place order was issued, and over 15 months since the court-issued stay expired. Yet the court prohibited the district court from ordering Whirlpool to bump the incumbent "regardless of the passage of time." Id at 121. The circuit court did permit bumping, however, of the individual whom the employer placed in the next-available position after a rightful place order already had been entered on the victim's behalf. Id at 122 .

10467 US 561 (1984).

61 Id at 579 (footnote omitted).

42 Id at 579 n 11 (citing Patterson and Local 189). The Supreme Court carefully limits make-whole relief to "actual victims" of discrimination. Firefighters, 467 US at 580. 
or a determination that such a remedy was necessary to make whole a proven victim of discrimination." ${ }^{33}$ The two passages are equivocal, and dicta at that. The lower courts, however, have considered the issue several times on the merits.

Lower courts have ordered bumping only rarely, when they identify interests regarded as more fundamental than the incumbent's interest in keeping his job. Most courts that have ordered bumping emphasize their desire to protect the institutional role of the courts in fashioning relief. For instance, bumping is awarded routinely after the employer has violated a prior court order to cease discriminating. ${ }^{44}$

The Eleventh Circuit ordered bumping in Walters $v$ City of Atlanta, ${ }^{45}$ based on the court's interest in discouraging recalcitrance and bad faith. The court relied on a non-exhaustive, noncontrolling list of factors. ${ }^{46}$ It noted first that the defendant had engaged in repeated acts of discrimination against Walters; second, that the defendant had exhibited "recalcitrance" by its subsequent retaliatory acts against Walters; third, that the position denied the plaintiff was unique; and finally, that the defendant could minimize the harm to the bumped incumbent by offering alternative employment. The court also emphasized in a footnote that the incumbent "was at least on inquiry notice, if not actually aware, of the controversy surrounding the directorship and Walters' claims to it when she was hired." 47 Thus, the court achieved its probumping' result in part by rejecting the usual presumption that bumped incumbents are "innocent." The court offered no guidance as to the type of facts sufficient to put an incumbent on inquiry

${ }^{43}$ Id at $576 \mathrm{n} 9$.

44 See, for example, Lee, $453 \mathrm{~F} 2 \mathrm{~d}$ at 1112 (arguing that the fact that another occupied the plaintiff"s denied position "obviously cannot prevent appropriate relief by a court of equity in vindication of the law and the Constitution" after the defendant violated a court order to desegregate). Although not a Title VII case, Lee guided subsequent courts confronting similar issues. See also Brewer, $790 \mathrm{~F} 2 \mathrm{~d}$ at 1522-23 (arguing that Congress's desire to enforce Title VII through voluntary settlement justified bumping after the defendant violated a settlement agreement); Sebastian v Texas Dept. of Corrections, 541 F Supp 970, 978 (S D Tex 1982) (awarding preliminary injunction instating plaintiff even if employer must bump incumbent); McCurdy v School Bd. of Palm Beach County, 367 F Supp 747, 752 (S D Fla 1973) (bumping issued as part of preliminary injunction, and school system ordered to offer the bumped incumbent principal the first available principal's job and to maintain his pay rate).

45803 F2d 1135, 1149-50 (11th Cir 1986).

${ }^{46}$ Id at $1150 \& \mathrm{n} 15$.

47 Id at $1150 \mathrm{n} 15$. Earlier in its opinion, the court noted that the employer was on notice that there was a substantial Title VII claim to the vacant position. Id at $1149 \mathrm{n} 12$. 
notice that another lays claim to the same job. ${ }^{48}$

Perhaps more important than the Walters enumeration of factors that justified bumping (and its implicit rejection of the expanded version of the rightful place doctrine) is its subtle reconceptualization of the interests at stake. Prior to Walters, courts usually perceived bumping as a penalty unfairly visited upon an incumbent. The Walters court turned that conception on its head:

To not allow the "bumping" of a direct beneficiary of repeated discrimination by the direct victim of the same acts of discrimination would penalize the plaintiff who won his suit but lost the race to fill the position he had been unlawfully denied.99

Before Walters, courts characterized bumping as penalizing the incumbent employee; after Walters, courts may see failing to bump as penalizing the victim.

Only one circuit has found the requisite compelling interest in the victim's Title VII rights alone. In Lander $v$ Lujan, ${ }^{\text {so }}$ the District of Columbia Circuit became the first court consciously to reject the rightful place doctrine in cases of one-on-one discrimination. Lander's employer essentially had demoted him from his toplevel administrative position in retaliation for Lander's criticism of the employer's affirmative action plan. ${ }^{31}$ The demotion violated $\S 704(\mathrm{a})$, which prohibits discriminating against an employee "because he has opposed any practice made an unlawful employment practice by" Title VII. ${ }^{52}$ The district court had ordered the employer to reinstate Lander in the more senior position because "absent 'bumping' the plaintiff's relief would be unjustly inadequate." $"$ s3

The appellate court determined that the relief ordered by the district court accorded with Title VII's make-whole policy. It found "no evidence that Congress intended to exclude bumping from the district court's arsenal of available alternatives." 54 Judge Silberman's opinion for the majority turned for guidance to remedies available under counterpart sections of the National Labor Relations Act (NLRA), upon which $\S 706(\mathrm{~g})$ was " expressly

\footnotetext{
48 Id at $1150 \mathrm{n} 15$.

19 Id at 1149 (emphasis added).

so 888 F2d 153 (DC Cir 1989).

s2 Id at 155 .

32 Id.

ss Id.

s4 Id at 156.
} 
modeled." "Bs Under the NLRA, the court observed, bumping is a "commonplace remedy." congressional intent to include bumping among the remedies available in Title VII. The court also noted that the EEOC had adopted bumping as an appropriate remedy for discrimination. ${ }^{57}$

In balancing the equities between the incumbent and the victim, the court concluded that neither the statute nor logic gave the former a "superior equitable claim to the job." ployer's interest in not having the workplace disrupted could not trump the victim's right to complete relief. As the court noted, "the employer's intentional discrimination created the disturbance by harming the plaintiff." 59

The Lander court's endorsement of bumping is broad, but not unqualified. ${ }^{60}$ The court carefully limited its holding to allow bumping only in disparate treatment cases, where discrimination is explicitly intended.$^{61}$ Lander also involved the demotion of the victim; a victim's claim to immediate reinstatement to his rightful position may be greater in demotion cases than in hiring and firing cases, which form the bulk of Title VII litigation. Similarly, the court took special note that the "impact of bumping on the innocent incumbent [was] relatively mild";62 one is left to wonder about the result if the impact had been more severe. Finally, the court implied that bumping might not be appropriate when vacancies appear frequently. ${ }^{63}$ Nevertheless, the court jettisoned the requirement that a court find "recalcitrance" or other bad faith behavior by the defendant before entering a bumping order. ${ }^{64}$ No other circuit has yet followed suit.

${ }^{85}$ Id (quoting Albemarle Paper, 422 US at $419 \& \mathrm{n} 11$ ). The NLRA is codified at 29 USC $\S 151$ et seq (1988).

se 888 F2d at 156.

s7 Id at 157 \& $\mathrm{n} 4$ (citing $29 \mathrm{CFR} \& 1613.271(\mathrm{a})(3)$ ).

88 Id at 157.

89 Id at 158 .

so See Jones v Rivers, 732 F Supp 176 (D DC 1990) (citing Lander, court awarded bumping when position sought was unique); EEOC v District of Columbia, Dept. of Human Services, 729 F Supp 907 (D DC 1990) (ADEA case, declining to award bumping when openings were frequent).

61 888 F2d at 157. The Lander court thus declined to review the possibility of a bumping order in disparate impact cases. Disparate impact cases do not require a showing of intentional discrimination, but merely proof that a rule or practice disadvantages protected groups. See Griggs v Duke Power Co., 401 US 424 (1971).

62 888 F2d at 156.

es Id at 158.

64 Id at 156. 


\section{The Propriety of Bumping Relief Under Title VII}

A court confronts two remedial alternatives when fashioning relief for the victim of discrimination: order the victim to await the next available vacancy for the illegally denied spot (rightful place), or order immediate placement of the victim in that position (bumping). Having examined the dramatic expansion of the rightful place doctrine as the preferred remedy, this Comment now addresses the propriety of bumping in the context of Title VII.

The analysis below suggests that bumping better comports with the text, history, and purposes of the Act. The traditional approach to bumping as a simple confrontation between the victim and the innocent incumbent must be reconsidered. Instead, the employer's act of discrimination should be viewed as a harm visited upon both the victim and the incumbent, requiring a vigorous response from courts. Treating displacement merely as a contest between two innocent actors, without considering the behavior that put them in jeopardy, is unhelpful and paralyzes equitable judgment. The Solomonic dilemma envisioned by the rightful place doctrine conjures no self-evident solution. It provides no grounds for choosing between the victim and the incumbent. Yet closer analysis offers Title VII grounds for making that choice, and suggests that the choice itself may be unnecessary.

\section{A. The Text of Title VII}

The remedial section of Title VII, $\S 706(\mathrm{~g})$, provides that upon a finding of liability for intentional discrimination,

the court may enjoin the respondent from engaging in such unlawful employment practice, and order such affirmative action as may be appropriate, which may include, but is not limited to, reinstatement or hiring of employees, with or without back pay ...., or any other equitable relief as the court deems appropriate. . . . No order of the court shall require ... the hiring, reinstatement, or promotion of an individual as an employee, or the payment to him of any back pay, if such individual ... . was refused employment or advancement or was suspended or discharged for any reason other than discrimination on account of race, color, religion, sex, or national origin or in violation of $[\S 704(\mathrm{a})]^{.65}$

os 42 USC \& $2000 \mathrm{e}-5(\mathrm{~g})$. Section 704(a) makes it unlawful to discriminate against an employee because the employee "has opposed any practice made an unlawful employment practice" by Title VII, or because the employee has assisted an investigation into possible Title VII violations. 42 USC $\$ 2000 \mathrm{e}-3(\mathrm{a})$. 
Section 706(g) thus explicitly authorizes the gamut of affirmative relief that would put the victim in the place she would have occupied but for the discrimination: reinstatement, hiring, and promotion. The importance of reinstatement-and its companion, backpay-is highlighted by its specific delineation; the text of $\S 706(\mathrm{~g})$ thus intimates that reinstatement should be a Title VII remedy of first resort. ${ }^{66}$

Some might argue that the rightful place doctrine also fits this textual preference for reinstatement. Section 706(g), one could argue, does not direct a court to order "immediate" reinstatement. The salient difference between a bumping remedy and a rightful place remedy is not substance but timing. Thus, accounting for textual ambiguity on the timing of the relief order, the rightful place remedy could be thought to fulfill the text's promise of reinstatement.

For two reasons, however, the text points away from a delayed application of reinstatement. First, the opening sentence of $\S 706(\mathrm{~g})$ has a parallel construction that authorizes injunctive relief (ordering the employer to cease discriminating) as well as affirmative relief. Few would argue that the mere absence of a timing specification in the first part (that is, an "immediately" before the words "enjoin the respondent") allows a court to delay application of the remedy once it finds liability. The unstated premise is that the injunctive relief will swiftly follow upon the liability determination. Similarly, the absence of a timing specification in the second part of the sentence should not, by itself, counsel delayed application of affirmative relief.

Second, $\S 706(\mathrm{~g})$ contemplates reinstatement with backpay. Backpay compensates the victim for pecuniary loss suffered between the time of the discrimination and the time the court finds liability. ${ }^{67}$ Backpay does not compensate the victim for pecuniary loss suffered after the finding of liability ("frontpay"). The fact that the text links reinstatement with backpay, not frontpay, indicates a preference for immediate reinstatement. Otherwise, the victim would not enjoy affirmative relief between the date of judgment and any delayed reinstatement. Needless to say, a court could order backpay, frontpay, and delayed reinstatement-the classic formulation of the rightful place remedy-consistent with

\footnotetext{
${ }^{6 B}$ See, for example, Darnell $v$ City of Jasper, 730 F2d 653, 655 (11th Cir 1984).

67 Backpay for discrimination occurring more than two years prior to the filing of a charge, however, is not authorized. See $\S 706(\mathrm{~g}), 42$ USC $\S 2000 \mathrm{e}-5(\mathrm{~g})$.
} 
the text of $\S 706(\mathrm{~g})$. But the close textual link between reinstatement and backpay slants resolution of the timing question in favor of immediate reinstatement.

Section 706(g), of course, does not explicitly authorize a court to order bumping. Some might suggest, therefore, that reinstatement is authorized only when no incumbent will suffer. Several strong textual reasons exist to doubt this construction of $\S 706(\mathrm{~g})$. First, $\S 706(\mathrm{~g})$ is simply silent on bumping. Cases involving bumping are a subset of reinstatement cases, which the text does mention. Conceptually, reinstatement involves the potential for incumbent displacement. Rather than specify each context in which a court may or may not order reinstatement, the statutory language grants authority to order reinstatement across a broad spectrum of contexts. Given the unqualified language authorizing reinstatement, the presumption should favor granting reinstatement in all cases, including bumping cases, rather than limiting the reinstatement remedy to narrow categories.

Second, Title VII elsewhere protects incumbents' vested interests in their jobs. Section 703(h) shields from court scrutiny the positions of incumbents hired pursuant to a "bona fide seniority system." If incumbent interests necessarily trump the textual preference for reinstatement, why does $\S 706(\mathrm{~g})$ not mention that fact? That the Act explicitly protects incumbents in some circumstances, such as the seniority system context, suggests that it does not afford the same protection where it does not do so explicitly. Congress could anticipate that the investigation and litigation stages of discrimination cases would last months or even years, and Congress must have known that employers could not afford to keep the disputed positions vacant until resolution of the controversy. If the foreseeable problem of the incumbent weighed heavily on the legislators' minds, Congress easily could have added an exemption from the reinstatement remedy for incumbents, just as it did for non-discriminatory behavior. Yet the text is silent on the issue.

Finally, $\S 706(\mathrm{~g})$ is directed at courts, not employers. In remedying discrimination, the court does no more than order reinstatement to the discriminatorily denied position. What the employer does to make that position available to the victim-whether bumping the incumbent or creating an equivalent position-is the employer's concern. On this view, the court does not order bumping

e8 42 USC $\$ 2000 \mathrm{e}-2(\mathrm{~h})$. 
at all. It orders reinstatement. Such an order perfectly fits within the parameters of $\S 706(\mathrm{~g})$. Of course, the balance of equities may caution against displacing an incumbent, and a court will rightly take that fact into account when ordering immediate reinstatement, ${ }^{69}$ but the text does not preclude such an order.

Thus, the language of $\S 706(\mathrm{~g})$ is permissive, neither requiring nor prohibiting bumping. Bumping is at least consistent with the text and perhaps favored by it. The legislative history helps discern the congressional intent behind the text. ${ }^{70}$

\section{B. The Legislative History of Title VII}

Congress did not consider bumping or rightful place relief explicitly during its debates on Title VII. ${ }^{71}$ The three considerations presented in this subsection, however, drawn from the legislative history of Title VII, suggest that Congress wanted to imbue $\S 706(\mathrm{~g})$ with a scope broad enough to include bumping as a remedy.

\section{Congress's general aspirations in drafting $\S 706(\mathrm{~g})$.}

Congress wanted Title VII remedies to reconstruct the employment circumstances that would exist in a nondiscriminatory world. The drafters of the 1972 amendment to $\S 706(\mathrm{~g})^{72}$ made it clear that they shared the courts' understanding that Title VII relief should make victims whole:

[T] he courts have stressed that ... [§ 706(g)] is intended to make the victims of unlawful discrimination whole, and that the attainment of this objective rests not only upon the elimination of the particular unlawful employment practice complained of, but also requires that persons aggrieved by the consequences and effects of the unlawful employment practice

\footnotetext{
${ }^{69}$ See Section III.A. for an argument that the equities favor displacement.

${ }^{70}$ In construing Title VII, the Supreme Court looks first to the text and then to the legislative history of the law. See, for example, American Tobacco, 456 US at 68.

${ }^{71}$ Congress's discussion of reinstatement largely recited $\S 706(\mathrm{~g})$ without elaboration. To illustrate: "The relief available [under the Act] is a court order ... directing the offender to take appropriate affirmative action; for example, reinstating or hiring employees, with or without back pay." 110 Cong Rec 11848 (May 25, 1964) (remarks of Senator Humphrey), reprinted in Legislative History -1964 at 3259 (cited in note 3).

${ }^{72}$ The amendment broadened the courts' authority to fashion make-whole relief by adding the phrases "but is not limited to" and "or any other" to this section (quoted in text at note 65).
} 
be, so far as possible, restored to a position where they would have been were it not for the unlawful discrimination. ${ }^{73}$

The Section-By-Section analysis of the bill stated that a broad reading of effective remedies was needed "to effectively combat the presence of employment discrimination."74 The congressional desire to eliminate the "consequences and effects" of employment discrimination argues in favor of reinstatement under even unpleasant circumstances. The passage indicates that the judicial creation of a nondiscriminatory world is limited only by what is "possible." Surely a court order immediately reinstating a discriminatee falls in that category.

Congress knew of the nonpecuniary values attached to employment when it enacted Title VII. That helps explain the inclusion of reinstatement among the available remedies. Congress did not choose to add a caveat to Title VII barring reinstatement if the remedy required displacement. Further, the fate of incumbents certainly entered the legislators' deliberations on Title VII. Congress debated at length the effect of Title VII on seniority rights. They settled on a compromise that protected incumbents' interests in seniority systems. ${ }^{75}$

\section{The National Labor Relations Act.}

The National Labor Relations Act (NLRA) protects the rights of workers to organize unions and to bargain collectively. ${ }^{76}$ It prohibits employers from discriminating against employees on the basis of union activity. ${ }^{77}$ Title VII echoes the NLRA's willingness to circumscribe the traditional power of employers to organize the workplace as they see fit.

Congress expressly intended to model remedies available in Title VII after NLRA remedies. ${ }^{78}$ Thus, it is no accident that the

73118 Cong Rec 7168 (Mar 6, 1972) (Section-By-Section Analysis of HR 1746, accompanying the Equal Employment Opportunity Act of 1972), reprinted in Legislative History of the Equal Employment Opportunity Act of 19721848 (GPO, 1972) ("Legislative History-1972").

${ }^{74} 118$ Cong Rec 4942 (Feb 22, 1972), reprinted in Legislative History-1972 at 1771 (cited in note 73 ).

${ }_{75}$ Section 703(h), 42 USC $\S 2000 \mathrm{e}-2(\mathrm{~h})$; see American Tobacco, 456 US at 72.

76 Pub L No 74-198, 49 Stat 449 (1935), codified as amended by the Labor Management Relations Act of 1947, Pub L No 80-101, 61 Stat 136 (1947), at 29 USC $\S 151$ et seq (1988). The rights to organize and to bargain collectively are found in NLRA § 7, 29 USC § 157.

77 NLRA § 8(a)(3), 29 USC § 158(a)(3).

78 Albemarle Paper, 422 US at 419 \& $n$ 11. See also Clark-Case memorandum (cited in note 10). Congress also.modeled the Equal Employment Opportunity Commission after the National Labor Relations Board. Equal Opportunity Act of 1962, HR Rep No 1370, 87th 
language of $\S 706(\mathrm{~g})$ is virtually indistinguishable from NLRA $\S$ 10(c), which authorizes "affirmative action including reinstatement with or without back pay."" As in Title VII cases, the victim of a prohibited employment practice under the NLRA has a presumptive right to reinstatement. ${ }^{80}$ Cases decided under the NLRA routinely award the reinstatement of victims that results in bumping incumbents. ${ }^{81}$ The familiar remedial experience with bumping under the NLRA therefore strongly suggests Congress intended the same relief in Title VII cases. ${ }^{82}$

\section{The Clark-Case memorandum.}

Advocates of the rightful place doctrine as an alternative to bumping often cite legislative history as foreclosing displacement. The Patterson court, for example, relied on legislative history to support its no-bumping rule. One of the "concessions" necessary for passage of Title VII, wrote the court, was "the unequivocal assertion by proponents of the legislation that it was not intended to be used to displace incumbent workers."

In support of its broad reading of the legislative history, the Patterson court quoted from an interpretive memorandum by Senators Clark and Case, co-managers of the bill. ${ }^{84}$ In a footnote, the court quoted only the italicized portion in this passage:

Cong, 2d Sess 19 (1962) (minority views of Representative Hiestand), reprinted in Legislative History-1964 at 2173 (cited in note 3).

7929 USC \& 160 (c).

so Note, Title VII Remedies: Reinstatement and the Innocent Incumbent Employee, 42 Vand L Rev 1441, 1459 (1989).

${ }^{81}$ Lander, 888 F2d at 156. See, for example, Mastro Plastics Corp. v NLRB, 350 US 270, 278 (1956) (strikers); Radio Officers' Union v NLRB, 347 US 17, 54 (1954) (ordinary discriminatees).

${ }_{82}$ Indeed, the Supreme Court has noted that courts may have greater power to fashion relief under Title VII than under the NLRA. Franks, 424 US at $769 \mathrm{n} 29$. Note that one circuit judge has questioned the applicability of NLRA bumping relief to Title VII cases. Lander, 888 F2d at 159 (R.B. Ginsburg concurring) (strike replacement workers more likely to know of dispute over position than Title VII incumbents).

83 535 F2d at 268. The Patterson court was not the first authority to contend that Congress intended to rule out bumping as a remedy. See Note, $80 \mathrm{Harv}$ L Rev at 1274 (cited in note 15) (deeming it "unlikely" that Congress intended bumping "in any circumstances"); William B. Gould, Employment Security, Seniority and Race: The Role of Title VII of the Civil Rights Act of 1964, 13 Howard L J 1, 8-9 (1967) (Title VII "at odds" with bumping, especially where discrimination antedates the effective date of the Act). These authorities rely on legislative history like the Clark-Case memorandum that, at most, derogates the use of bumping in seniority system cases arising from pre-Act discriminatory practices. The cited legislative history hardly supports the view that Congress barred bumping "in any circumstances."

st The Supreme Court has recognized the "authoritative nature" of the Clark-Case 
Title VII would have no effect on established seniority rights. Its effect is prospective and not retrospective. Thus, for example, if a business has been discriminating in the past and as a result has an all-white working force, when the title comes into effect the employer's obligation would be simply to fill future vacancies on a non-discriminatory basis. He would not be obliged--or indeed, permitted-to fire whites in order to hire Negroes, or to prefer Negroes for future vacancies, or, once Negroes are hired, to give them special seniority rights at the expense of white workers hired earlier. ${ }^{85}$

As the context indicates, Clark and Case wrote their comment on bumping in their discussion of seniority systems. The no-bumping rule, then, seems applicable only in the narrow category of cases dealing with seniority systems-not, as the court's statement and selective excerpt suggest, in all cases. Although this interpretation would not alter the result in Patterson itself (because it dealt with seniority system discrimination), it refutes the subsequent extension of the rightful place doctrine to non-seniority system discrimination cases. Further, the full quotation supports the view that Congress intended to shield only pre-Act seniority system discrimination from the bumping remedy. ${ }^{86}$ The authors emphasized that the new law "would have no effect on established seniority rights."

The celebrated memorandum disfavors only the bumping of senior white employees in order to make room for junior minorities in seniority system cases. Moreover, the memorandum supports preserving only pre-Act seniority rights. If relevant at all, the Clark-Case memorandum fortifies the view that Congress did not intend to prevent bumping generally.

\section{The Purposes of Title VII}

A court should determine the appropriateness of a proposed

memorandum. See Firefighters, 467 US at $581 \mathrm{n}$ 14. Nevertheless, two scholars have seriously challenged the memorandum's interpretation of Title VII. Cooper and Sobol, 82 Harv $\mathrm{L}$ Rev at 1611-14 (cited in note 12).

ss 535 F2d at 268 n 7 (quoting Clark-Case memorandum (cited in note 10)).

so See also 110 Cong Rec 7207 (Apr 8, 1964) (statement of Justice Department prepared at the request of and placed in record by Senator Clark): "[I]t has been asserted that Title VII would undermine vested rights of seniority. This is not correct. Title VII would have no effect on seniority rights existing at the time it takes effect." (quoted in Franks, 424 US at 759-60 (emphasis added)). Note, though, that the Supreme Court equated pre-Act and postAct seniority systems in American Tobacco. See note 29. 
remedy in light of the purposes of the Act. ${ }^{87}$ The Supreme Court has identified two primary goals in the remedial provisions of Title VII: deterring future acts of discrimination and providing makewhole relief to the victim. ${ }^{88}$ This subsection argues that, in most cases, the best way to support these purposes is to reinstate the victim to the position she would have occupied absent the discriminatory acts, even if the reinstatement will cause the displacement of an innocent incumbent.

\section{Deterrence.}

A fundamental goal of the Act is to deter future acts of discrimination by all employers, not just the defendant. Under the deterrence theory, relief should provide a "spur or catalyst which causes employers and unions to self-examine and to self-evaluate their employment practices and to endeavor to eliminate, as far as possible, the last vestiges" of prohibited discrimination from the workplace. ${ }^{89}$ An award merely of backpay and/or frontpay reinforces the impression that employers can purchase discrimination rights in the courts by "buying off" the plaintiff. Courts should not enable employers to circumvent Title VII by substituting money damages for reinstatement. ${ }^{90}$ Failure to award reinstatement, even when an incumbent must be displaced, will not encourage the critical self-examination of employer conduct so important to Title VII.

Bumping, on the other hand, enhances the deterrence rationale of Title VII remedies. First, it demonstrates to the employer that it will gain nothing by discrimination. After the suit, the victim will occupy the exact position the employer sought to deny her. An award of backpay and frontpay, even coupled with rightful place relief, permits the employer to continue to deny-or at least to delay significantly - the resumption of the job by the victim. The employer's basic discriminatory choice has been allowed to stand, even if the employer suffers the out-of-pocket expenses of court costs and compensatory pay. Some employers may be willing to pay these costs in order to satisfy their discriminatory desire to oust the victim. Bumping ensures that the employer will have al-

\footnotetext{
87 Aloemarle Paper, 422 US at 417.

s8 Id at 417-18.

so Id (quoting N.L. Industries, 479 F2d at 379). See also Walsdorf $v$ Board of Commissioners, 857 F2d 1047, 1054 (5th Cir 1988).

${ }^{\circ}$ See Brewer, $790 \mathrm{~F} 2 \mathrm{~d}$ at $1523 \mathrm{n}$ 9, adopting the rationale of Banks $v$ Burkich, 788 F2d 1161, 1164 (6th Cir 1986) (bumping remedy to vindicate First Amendment rights).
} 
most nothing to show for its effort except added costs; it seeks to remedy the discrimination itself, not just the resulting economic harm. That fact can only add to the deterrence value of the relief.

Second, the failure to order bumping allows employers to avoid a reinstatement order by quickly hiring another employee to fill the wrongfully denied position. ${ }^{91}$ It encourages strategic behavior by employers to subvert the fundamental purposes of Title VII.

Third, bumping adds to the discriminating employer's cost of doing business. The employer loses the benefit of the incumbent's acquired experience, plus any resources the employer devoted to training that employee. The newly instated victim will need time to adjust to the position, adding to the employer's training costs and reintroducing initial efficiency losses. ${ }^{92}$ Employer administrative costs also add to expenditures. These increased costs make the discriminating employer less efficient and competitive relative to nondiscriminating employers. Because discriminatory conduct is avoidable, the employer might alter its practices in order to preserve the vitality of its ongoing business. ${ }^{93}$

Fourth, victims might be more inclined to instigate legal action against employers under a pro-bumping regime. Victims may feel that compensatory pay, especially in light of the long legal battle necessary to get it, does not justify the effort required to win a Title VII suit. The prospect of reinstatement immediately upon establishing liability might add to the ex ante likelihood that victims will challenge the employer's behavior. More challenges to discriminatory behavior will add to the enforcement of Title VII, making it more likely that discriminatory conduct will be discovered and remedied. An increase in the likelihood that courts will uncover and penalize violations should lower the number of transgressions ex ante.

Finally, employers will have to shoulder the burden associated with remedies available to the bumped employee. These remedies

11 See Banks, 788 F2d at 1165; Lander, 888 F2d at 159 (R.B. Ginsburg concurring).

92 In cases where the court reinstates a victim to a position she previously held, these costs will be lower. Yet even in these cases, some efficiency losses will occur, depending on changes in procedure, technology, the amount of time required for resolution of the litigation, and similar factors.

os See John J. Donahue III, Is Title VII Efficient?, 134 U Pa L Rev 1411 (1986); Richard A. Posner, The Efficiency and Efficacy of Title VII, 136 U Pa L Rev 513 (1987); John J. Donahue III, Further Thoughts on Employment Discrimination: A Reply to Judge Posner, $136 \mathrm{U}$ Pa L Rev 523 (1987). Both commentators agree that Title VII will tend to drive discrimination from the market, although Judge Posner argues that the change will occur too quickly to be efficient. 
might include compensatory pay to the incumbent and an award for damages. ${ }^{94}$

Deterring future discrimination through bumping admittedly will disrupt the workplace. Working relationships will be severed, retraining will be necessary, lives will be rearranged. ${ }^{95}$ The employer undoubtedly would prefer to preserve the settled expectations arising from the status quo. But as the Lander court noted, the employer's preferences cannot determine the remedies for Title VII victims..$^{96}$ In short, the employer caused the "disruption." Perhaps more fundamentally, workplace disruption adds to the deterrence value of the relief. Title VII was intended precisely to "disrupt" the discriminatory workplace.

\section{Make-whole relief.}

The second purpose of Title VII's remedial provision is to place the victim in the position she would have occupied absent the discrimination-to make the victim whole. ${ }^{97}$ Immediate reinstatement is the sole remedy that, together with backpay; can make amends for the wrongs done the victim. It alone puts her in the position she would have occupied-to the extent the court can divine that position from the facts before it-absent the discrimination. ${ }^{98}$

No other remedy is consistent with the fundamental makewhole purpose of Title VII. The Supreme Court has directed district courts to "fashion the most complete relief possible" in cases of Title VII violations. ${ }^{99}$ Delayed reinstatement-reinstatement at the next available opening-is not the most complete relief possible. When the denied position is an upper-level management or other supervisory job, for example, openings may be scarce. This requires the victim to wait, denying her the position from which she was unjustly and illegally excluded. The job may also have required specific or rare skills, ${ }^{100}$ for which there really is only one

24 For a discussion of possible relief for the displaced incumbent, see Section III.C.

98 Patterson, 535 F2d at 268.

96 888 F2d at 158 .

97 Teamsters, 431 US at 372 (citing Franks, 424 US at 769).

98 Of course, not even immediate reinstatement can completely undo the wrongs wrought by prejudice. Reinstatement cannot compensate the victim adequately for the humiliation and shame of being subjected to race or gender prejudice, for the delays suffered in the courts, or for the actual time the victim missed in the job. But immediate reinstatement goes much further toward that end than a court order that says, in effect, wait until the discriminating employer has a vacancy.

92 Franks, 424 US at 764.

100 See Walters, 803 F2d 1135. 
available position. Using the rightful place doctrine in such circumstances effectively means that the victim will never obtain the job. Even where the disputed position is common, or opens up frequently, every moment of delay is one moment short of granting the victim "the most complete relief possible."101

Offering the victim frontpay and backpay while she waits for the elusive job opening does not by itself compensate her completely for the loss of the position. While frontpay and backpay are critical to make-whole relief-they at least prevent the victim from having to shoulder the financial strains caused by the employer's behavior-they do not substitute for the nonpecuniary losses the victim suffers. ${ }^{102}$ "Salary is not the only apogee in our hierarchy of values." ${ }^{103}$ Responsibility, experience, and training are also among the rewards for which the discriminatee applied and that the employer wrongfully denied. Especially when the job requires special skills or is supervisory, the denial of reinstatement cheats the victim of these rewards. Requiring her to wait for a vacancy also sets her further back in experience, which may retard her future prospects for subsequent promotions and professional growth, and compound the effects of the original discrimination.

\section{Circumstances Under Which Courts Should ORDER BUMPING}

Given the presumption in favor of bumping, this Section examines circumstances where equitable considerations might overcome that presumption. Most restraints previously placed on bumping are not defensible; bumping is inappropriate only in seniority system cases. This Section also demonstrates that courts can shield bumped incumbents from the harshest economic consequences of displacement.

101 Courts should be willing to reverse a district court's denial of bumping relief as an abuse of discretion. The Supreme Court has emphasized that even a district court's wide discretion under $\S 706(\mathrm{~g})$ is circumscribed by Title VII's command to make the victim whole. Albemarle Paper, 422 US at 418,421 . Title VII obliges district courts to fashion the most complete relief possible. When they fail to do so by denying a bumping request, the appellate court should reverse.

102 Some may dispute the notion that monetary compensation alone cannot make the victim indifferent between discrimination and nondiscrimination. Whatever the merits of that view, and leaving aside the feasibility of large awards, Congress's judgment in $\S 706(\mathrm{~g})$-which provides for reinstatement-is otherwise.

${ }^{103}$ Lee, 453 F2d at 1109. 
A. Problems with Current Limitations on Bumping

The decision whether to bump an incumbent to make room for the Title VII victim, or to force the victim to await rightful place relief, ultimately hinges on the court's equitable judgment. Courts often give limited application to bumping based on the following factors: the perceived unfairness to innocent incumbents; the frequency of openings for the position at stake; the possibility of workplace antagonism and disruption; and the limited nature of the employer's acts of discrimination. None of these factors provides a sound basis for disfavoring bumping.

1. Unfairness to the innocent incumbent.

The equitable case against bumping rests principally on the fact that the incumbent did not participate in the employer's wrongdoing. If the incumbent actually helped to participate in the discrimination by conspiring with the employer, the incumbent's equitable claim would be negligible. If the incumbent even had knowledge of the wrongdoing, his equitable reliance interest in the job diminishes.

Derogating the incumbent's equitable claim on the ground that the incumbent was on "inquiry notice"104 is inappropriate, however. The practical problems of applying the inquiry-notice theory are staggering. The mere fact that an employer has discriminated against another in promotion or hiring does not mean that the incumbent knew or should have known about it. Indeed, given the consequences, the astute employer will seek to conceal acts of discrimination. Even if the victim has sued already, to require an applicant to check court records around the country before accepting a job (or, more directly, to ask the employer about incidents of discrimination in comparable jobs) seems unworkable. Courts must confront the fact that bumping will necessarily harm the interests of one who is usually blameless. ${ }^{305}$

When balancing this equity interest of the incumbent, courts should consider that the incumbent's claim arises from a discriminatory act. Although this does not implicate the incumbent directly, it does change our intuitive judgment about which of the

104 See Walters, 803 F2d at $1150 \mathrm{n} 15$.

108 The analogy to NLRA bumping relief falters here slightly. The chances are much greater that the person hired to replace the striker has actual knowledge of the dispute than does the innocent incumbent in a standard Title VII case. Clark, 38 Cath U L Rev at $816 \mathrm{n}$ 112 (cited in note 30 ). Even a non-striking union discriminatee likely will have been informed of the discrimination by the union. 
two "deserves" the position. One person, the victim, lays claim to the job by virtue of her merit: but for an illegal act she would now hold the position. The other, the incumbent, lays claim to the job by virtue of being the beneficiary of another's illegal act. The Walters court offered a helpful conceptualization of the interests at stake. Refusing to bump the beneficiary of discrimination penalizes the victim of that same discrimination. ${ }^{106}$

To help focus the equitable problem, consider a dilemma involving stolen property. One might conclude that the incumbent's position in bumping cases is rather like that of an unwitting bystander who is given the victim's stolen property by a crook. Although we certainly would not blame the bystander for the burglar's act, we would have little trouble requiring him to return the stolen property to the original owner. And we would have little trouble dispensing with the bystander's equitable claim to the victim's property. But, especially against the backdrop of a statutory presumption, we would want to give the owner her property back. We would want to place the bystander's loss-if any-on the burglar, not the original owner. ${ }^{107}$

Advocates of the rightful place doctrine as an alternative to immediate displacement emphasize the harm and perceived unfairness to the innocent incumbent that bumping may cause. This argument ignores several key points. First, Title VII focuses fundamentally on equitable relief for victims of discrimination, not protection of incumbents. Second, rightful place relief itself will cause harm to innocent third parties. Rightful place relief will disadvantage future job applicants who will have to wait in line behind the victim when the next vacancy occurs. ${ }^{108}$ Third, it is unrealistic to suppose that remedying past and present discrimination will be cost-free to members of the groups that benefited from that discrimination. Title VII embodies a legislative judgment that racism and sexism have burdened nondominant groups for too long. ${ }^{109}$

\footnotetext{
108 Walters, 803 F2d at 1149. See discussion in text at notes 45-49.

${ }^{107}$ In fact, the law of property tracks this conclusion. For example, the universal rule is that "a sale of [stolen] merchandise, though to a bona fide purchaser for value, does not divest the person from whom stolen, of title." Schrier v Home Indemnity Co., 273 A2d 248, 250-51 (DC App 1971).

${ }_{108}$ Paul J. Spiegelman, Remedies for Victim Group Isolation in the Workplace: Court Orders, Problem Solving and Affirmative Action in the Post-Stotts Era, 29 Howard L J 191, 237-38 (1986). Bumping combined with rightful place relief for the displaced incumbent (see text at note 122) will also produce this harm to future job applicants. The point here is only that rightful place relief is not costless to third parties.

${ }^{100}$ See Legislative History-1964 at 2153 (House Judiciary Committee Report) (cited
} 
Finally, the argument from fairness simplistically treats the dilemma as a two-dimensional confrontation between the victim and the incumbent. In reality, the employer stands in the middle. ${ }^{110}$ The harm done the incumbent by bumping is a direct result of the employer's act, not the victim's. The victim is at least as innocent as the incumbent. Therefore, the incumbent's equitable claims have most persuasive force against the discriminatory employer. The displaced worker's equity interests can be vindicated in a separate cause of action against that employer. ${ }^{111}$

2. The frequency of openings for the position at stake.

The case for bumping is often thought most compelling when. the position at stake is unique or extremely rare. ${ }^{12}$ Certainly the victim's equitable claim is strongest in such cases, but it is precisely those cases in which the incumbent's equitable claims are strongest as well. The bumped incumbent will have just as difficult a time finding adequate substitute employment as the victim would. Thus, courts might limit bumping to relatively common positions. The difficulty with this approach is that the converse of the above proposition is also true. Where openings are frequent, the equitable claims of both the victim and the incumbent are diminished. Insofar as the equitable claims of either person are based on the relative uniqueness of the job or the infrequency of openings, the stakes of the victim and the incumbent rise and fall together. Therefore, one cannot sort out cases appropriate for bumping from those inappropriate for bumping according to frequency of availability.

\section{Antagonism and workplace disruption.}

Opponents of bumping argue that employee displacement will disturb work relations. ${ }^{113}$ But antagonism in the workplace generally does not preclude Title VII relief. Hostility is present in all litigation. If majority group hostility is allowed to justify limiting

in note 3) ("Through the action we take on this important bill, we in Congress can do much to conquer the forces of hatred and intolerance which have been unleashed in our land ....").

110 One commentator, in fact, has identified at least six separate perspectives at stake in discrimination cases. Spiegelman, 29 Howard L J at 234 (cited in note 108).

11 See text at notes 119-28.

112 See Lander, 888 F2d at 158 (director of unique cyclorama). See also Note, 42 Vand L Rev at 1465 (cited in note 80 ).

11s See, for example, Patterson, 535 F2d at 268-69. 
relief available to victims, Title VII's make-whole policy is slighted. Accordingly, courts routinely award relief despite the potential backlash from the employer and co-workers. ${ }^{114}$ Title VII has less interest in preserving the collegiality of the discriminatory workplace than it does in eradicating discrimination. In addition, to the extent that bumping deters the initial discriminatory denial, these concerns will not arise. The potential existence of workplace antagonism and disruption should not defeat bumping relief.

4. The limited nature of the employer's acts of discrimination.

Courts also consider the probativeness of repeated employer acts of discrimination. ${ }^{116}$ Such acts elevate the importance of the court's interest in vindicating its own power to right past wrongs. They also extinguish whatever sympathy the court might have had for the employer's hardship.

But courts should not consider-let alone require-multiple discriminatory acts, recalcitrance, or bad faith prior to entering a bumping order. The incumbent does not gain a superior claim to the job by virtue of the fact that the employer engaged in a lone act of discrimination. Nor can the employer, for its part, claim refuge in a single act-every act of discrimination is prohibited. Title VII does not vary the relief available to victims according to a scale of employer mendacity; one act is enough to bring on the full range of Title VII's remedies. ${ }^{116}$

\section{B. Where Bumping Is Inappropriate}

Having established the superior equitable and statutory claim of the victim to the position, it remains to be seen under what circumstances a court should decline to bump. The one area in which

${ }^{114}$ See, for example, Banks, 788 F2d at 1165; Bethlehem Steel, 446 F2d at 663; In re Hopkins, 81 Bankr 491, 495 (W D Ark 1987); Sebastian v Texas Dept. of Corrections, 541 F Supp 970, 976, 978 (S D Tex 1982).

${ }_{115}$ See, for example, Walters, $803 \mathrm{~F} 2 d$ at 1149-50; see text at notes 45-49.

${ }^{118}$ Another consideration that courts have weighed is whether the employer's discrimination was intentional. See Lander, 888 F2d at 157. Discrimination, whether intentional or not, denies victims their jobs; the victim's interest does not vary with the intentional quality of the illegal act. This suggests that bumping should be available in disparate impact as well as in disparate treatment cases. However, application of bumping to disparate impact cases, which frequently involve large numbers of plaintiffs, will introduce complications relating to class identification and mass disruption. See Barbara L. Schlei and Paul Grossman, Employment Discrimination Law 1231-32 (ABA, 2d ed 1983). This Comment focuses on disparate treatment cases. 
denying a bumping remedy might be appropriate is seniority system litigation. ${ }^{117}$ As an initial matter, the powerful arguments supporting displacement apply to the seniority system context. Yet in these cases, a rightful place remedy might be more consistent with Title VII and its legislative history. ${ }^{118}$ The doctrine developed as a means to provide victims with some relief without sacrificing the Act's prospective character. As such it is defensible, but only as long as courts cabin the rightful place remedy within the boundaries established by its historic origins.

\section{Relief for the Bumped Incumbent}

In a profound sense, the displaced incumbent is also a victim of the employer's discrimination. The fate of the bumped incumbent thus also has Title VII significance. Although the incumbent's interest should not prevent the victim's reinstatement, the incumbent should have recourse against the employer. ${ }^{118}$

By providing relief to the bumped incumbent, a court diminishes any unfairness to him. ${ }^{120}$ It also enhances Title VII's deterrence policy. The court will oblige the employer not only to employ the victim, with all the added costs that entails, but to relieve the bumped incumbent as well. The employer thus will have to sustain two employees where only one job is available. ${ }^{121}$

Using its $\S 706(\mathrm{~g})$ discretionary power, a court could order the employer to provide the bumped incumbent with the next available comparable vacancy. Until the substitute position is found, the employer should have to pay the bumped incumbent at his current

${ }_{117}$ A court will also want to avoid bumping in the presumably rare circumstance in which the remedy would lead to an employer's financial insolvency. The victim gains little from being reinstated to a job that does not exist. See Iris Burke and Oscar Chase, Resolving the Seniority/Minority Layoffs Conflict: An Employer-Targeted Approach, 13 Harv CR-CL L Rev 81, 111-15 (1978) (arguing for an insolvency exception to a "full payroll" layoff remedy whereby courts require employers to pay both minorities and nonminorities).

118 See text at notes 10-20.

110 A detailed examination of the possible remedies available to a bumped incumbent is beyond the scope of this Comment. For a general discussion of such remedies under Title VII, contract, and state law theories, see J. Hoult Verkerke, Compensating Victims of Preferential Employment Discrimination Remedies, 98 Yale L J 1479, 1485-90 (1989).

${ }^{120}$ Note, however, that "diminishing" the harm to the incumbent ordinarily will not completely eliminate it. Just as the victim suffers when excluded from the disputed position, so too the incumbent will suffer when the court bumps him. A court exercising its Title VII make-whole power can only minimize the resulting damage.

121 Under rightful place relief, the employer must also support two employees. However, the analysis in text at notes $92-93$ suggests that the costs of this double support will be higher under a bumping regime than under a rightful place regime. 
rate for any lost wages. ${ }^{122}$ Such a post-bumping order would essentially constitute "rightful place" relief for the incumbent.

Because private agreements cannot stand between discriminatees and Title VII relief, ${ }^{123}$ a court should be prepared to order the employer to breach any employment contract with the incumbent. At the same time, the court could order the employer to pay any damages for breach. ${ }^{124}$ However, a remedy sounding in state contract law faces the dual problem of potential federal preemption and the need for a uniform federal remedial system. ${ }^{125}$

In most cases, no contract will govern the relationship between the incumbent and the employer. In these employment-at-will cases, the displaced incumbent will have relied to his detriment on employment expectations. Incumbent employees are certainly entitled to presume that the employer will abide by the law. The innocent incumbent may well have lost other opportunities by taking a position with the discriminating employer. In some states, the incumbent will have a cause of action against the employer for breach of an implied employment contract. ${ }^{126}$

Even if no such state law remedy is available, the bumped incumbent may have an action for damages under Title VII itself. One commentator has found a statutory basis for equitable relief for incumbents rooted in the language and history of Title VII. ${ }^{127}$ Even barring that approach, a court could utilize its general equitable power to "secure complete justice" and protect the incumbent's detrimental reliance. ${ }^{228}$

\section{CoNCLUSION}

The courts' first tentative movements toward bumping are steps in the right direction. Nevertheless, the constraints placed on bumping thus far are improper. The rightful place doctrine developed as a compromise that allowed courts to address the limited

122 Clark, 38 Cath U L Rev at 816 (cited in note 30). This type of incumbent relief has federal court precedent. McCurdy, $367 \mathrm{~F}$ Supp at 752 (school system ordered to offer the bumped incumbent principal the first available principal's job and to maintain his pay rate).

${ }^{123}$ Chesapeake and Ohio Ry. Co., $471 \mathrm{~F} 2 \mathrm{~d}$ at 592 (relief order modifying collective bargaining contract because union and employer may not compromise Title VII rights); Spiegelman, 29 Howard $L \mathrm{~J}$ at 244 (cited in note 108) (court's equitable power to order remedies should not be limited by private agreements made by a wrongdoing employer).

124 See id at $239 \mathrm{n} 145$.

125 Verkerke, 98 Yale L J at 1489-90 \& n 71 (cited in note 119).

${ }^{128}$ See Grouse $v$ Group Health Plan, Inc., 306 NW2d 114 (Minn 1981) (awarding reliance damages in employment-at-will case).

${ }_{127}$ Verkerke, 98 Yale L J at 1490-96 (cited in note 119).

128 Id at 1496. 
problem of the lingering effects of pre-Act discrimination without sacrificing the prospective quality of Title VII. In its time, the doctrine served its purpose. But courts expanded it beyond its original boundaries until it became the reigning standard for relief from discrimination and effectively blocked true make-whole relief for victims. The rightful place doctrine also diluted the deterrence effects that the drafters of Title VII hoped to produce.

Reinstatement, even if it requires bumping, accords with the text, history, and purposes of Title VII. The equitable criteria established by Title VII strongly point in the direction of greater use of bumping. Courts no longer should conceive of the problem as one that pits the victim of discrimination against the displaced incumbent. Rather, both the victim and the incumbent suffer at the hands of the discriminating employer. Courts can devise the bumping order so as to minimize harm to innocent third parties. Courts could, at a minimum, offer bumped incumbents backpay, frontpay, and the first available vacancy.

The court that fails to order the immediate reinstatement of a Title VII victim has validated the employer's prohibited choice. No amount of mitigation available in the court's arsenal of prophylactic and compensatory weaponry-backpay, frontpay, rightful place-can alter the stark fact that, at the end of the day, the basic act of discrimination (the sort prompting the statute and the suit, after all) has been allowed to stand. It is an odd antidiscrimination regime that punishes, yet hesitates to undo, the bigot's work. The fact that the discriminatory employer has interposed an innocent third party between the victim and "the most complete relief possible" should not prevent a court from fulfilling its statutory and equitable responsibilities. 